\title{
SOLAR DEVELOPMENT IN UZBEKISTAN. STEP 1: SOLAR DATA COMPILATION
}

\author{
Nilufar Avezova ${ }^{2}$, Shirin Sadullaeva* ${ }^{1}$, Ergashali Rakhimov ${ }^{1}$, Nizomjon Usmonov ${ }^{3}$, \\ ${ }^{1}$ International solar energy institute, \\ ${ }^{2}$ Physical - Technical Institute of Academy of Science of Uzbekistan, \\ ${ }^{3}$ JSC Uzbekenergo
}

*Shirin Sadullaeva; avezov@uzsci.net; sch.sadullaeva@yandex.ru

\begin{abstract}
Solar radiation resource data serve as fundamental information for programs of large-scale deployment of solar energy technologies. While solar resources in the Republic of Uzbekistan are estimated to be significant based on limited information, comprehensive understanding requires considerably more data and analysis in order to optimize the process of planning and siting solar energy power plants. This paper highlights the analysis of the four-year of solar resource measurements from new ground meteorological stations in Uzbekistan which were installed within the framework of the project of the Asian Development Bank TA 8008 "Development of solar energy in Uzbekistan" in 2013.The current study should have significant applications for preliminary technology selection, power plant modeling, and resource forecasting. The analysis uses4-year (January 2013-December 2016) data from 6 stations located in the southeastern part of the republic based on ten-minute measurements of Global Horizontal Irradiance (GHI), Diffuse Horizontal Irradiance (DHI), Direct Normal Irradiance (DNI), and related meteorological parameters.
\end{abstract}

Key words: solar radiation, ground-based measurements, solar resources potential

\section{Introduction}

The amount of solar energy incident on the world's land area far exceeds total world energy demand. Solar energy thus has the potential to make a major contribution to the world's energy needs. The annual solar resource varies considerably around the world. These variations are influenced by several factors, including proximity to the equator, cloud cover, and other atmospheric effects. The Earth's surface, on average, has the potential to capture around 5.4 GJ (1.5 MWh) of solar energy per square meter a year [1]. 
When talking about the deployment of solar energy projects, carrying out their feasibility studies within the country or in regions, on the whole, precise information on the available solar resources needs to be prioritized. The solar resources information facilitates policies and decision making processes of the different technologies to be used, as well as the investments. At the same time, the geographic analysis of solar resource assessment is frequently the first step in solar technology deployment in that particular region [2].

Until 2008 availability of solar radiation maps of Uzbekistan was quite limited. Besides worldwide data sets in coarse resolution like National Aeronautics and Space Administration (NASA) [3] there was no solar map for Central Asian region. Additionally, time-series and maps based on satellite-based measurements and model-derived solar radiation values of DNI and GHI were able to be obtained from the Meteonorm software [4]. In 2007, the National Renewable Energy Laboratory (NREL)released the 1991-2005 update to the 1961-1990 National Solar Radiation Data Base (NSRDB), a 30-year data set of measured and modeled solar radiation and accompanying meteorological data. In 2010 an updated version was released by NREL, which then covered entire Uzbekistan. Meanwhile several commercial satellite-derived data sets became available like 3TIER (2011), the Solemi data set of DLR (DeutschesZentrumfürLuft und Raumfahrt - German Aerospace Center), the iMaps data of GeoModel Solar [5], and the data from IrSOLaV. But the uncertainty of solar radiation data in Uzbekistan is still very high.

Preliminary evaluation shows that the total technical potential of using solar energy in Uzbekistan at the current stage is 176.8 million tons of oil equivalent, which amounts to only $0.34 \%$ of its gross potential [6]. However, even this figure is 3 times more than the annual production of hydrocarbon fuel in the country. Uzbekistan has publicly declared its desire to become a regional hub for solar energy and build four gigawatt solar power plants by 2030. The Asian Development Bank (ADB) also included Uzbekistan as an Asia Solar Energy Initiative assistance recipient in 2010, due to its abundant sunlight and wide-open natural spaces. With assistance from the ADB, Uzbekistan established the International Solar Energy Institute (ISEI), developed a road map for solar energy development with action plans and enabling policies, and a pipeline of solar projects. In light of these commitments, 6 meteorological observing stations were installed within the Republic. These monitoring stations that began deployment in January 2013 are designed to provide publicly available data for three major purposes: immediate data for project developers, data for solar resource tool development, and data for satellite-model development and validation. The paper summarizes meteorological stations implementation, and includes a complete analysis for the first 4 years of data.

\section{Meteorological stations siting and instrumentation}

While choosing sites for meteo-stations installationthe consulting team has visited a total of 36 pre-selected sites and studied their features:

18 of them are located near transformer stations;

5 of them are located on free flat-land areas;

13 of them are located near existing weather stations. The installation of the measurement equipment near currently operating weather stations has several advantages: the availability of 
Vol 2, Number 2, 2017

ISSN: 2548-0332

doi: 10.23884/IJESG.2017.2.2.01

qualified personnel, a good organization of the data collection and transfer system and physical security of the equipment.

The final sites meet following criteria:

-Spatial representativeness - locations should be representative of the climate of the region, and not heavily influenced by unique local factors;

-Temporal stability -evaluation ofthe risk of human encroachment over time and the chance the site will close due to the sale of the land or other factors;

-Relatively easy year round access by vehicle for installation and periodic maintenance;

-Locations near existing or former observing sites with long records of daily precipitation and maximum and minimum temperature;

-Locations near transformer substations;

-Lands used for agricultural purposes or lands which would require resettlement of local residents should not be considered.

A more detailed study of these sites and discussion with stakeholders leaded to 6 sites (Fig.1, Tab. 1) for ground measurement stations located in the following regions of the country [7]:

- Samarkand

- Navoi

- Kashkadarya

- Surkhandarya

- Namangan

- Tashkent

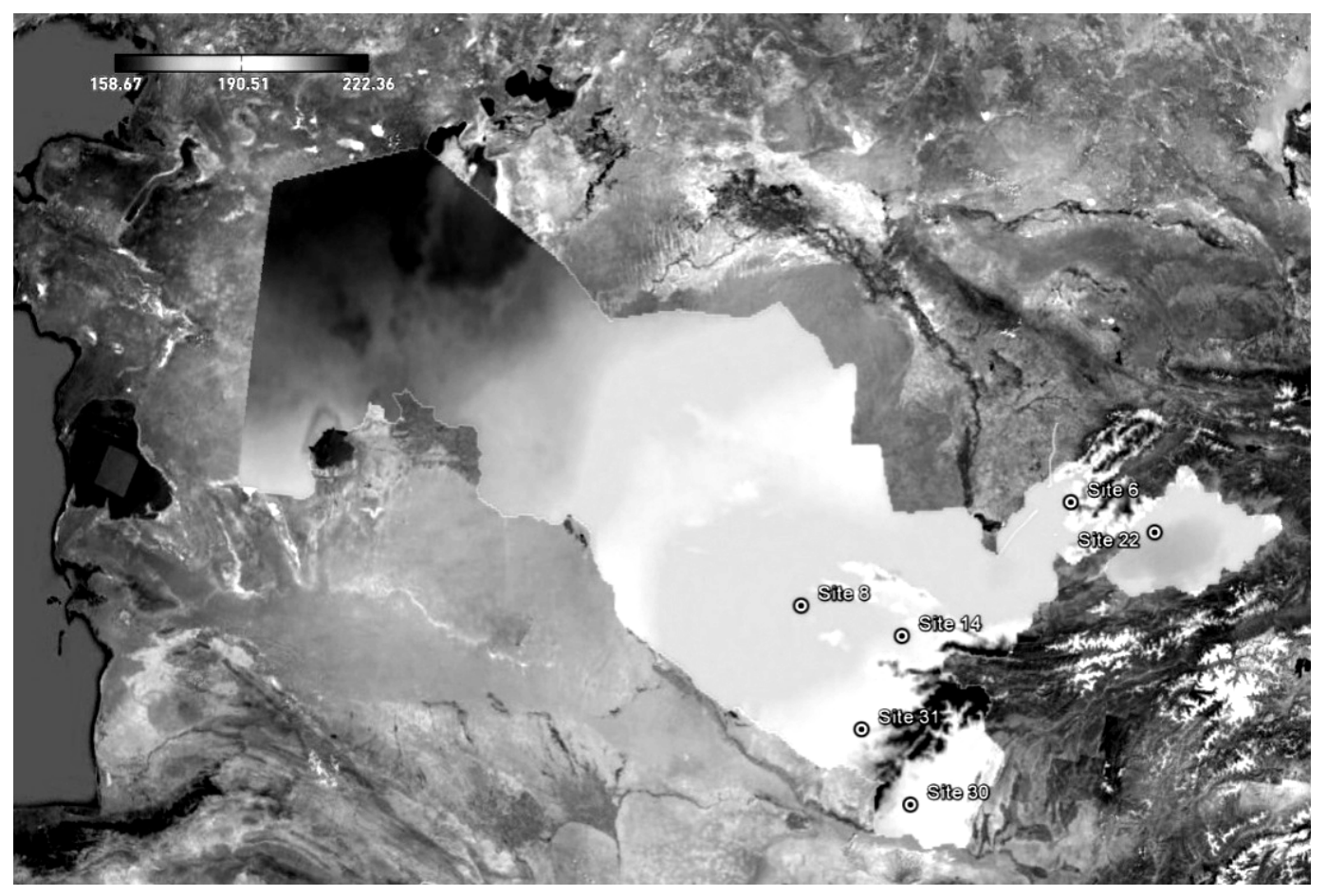

Fig.1. Ground meteo-station locations and (GHI (W/m2 /year $\mathrm{kWh} / \mathrm{m} 2$ year) source: ADB Roadmap to Solar energy development in Uzbekistan 
The coordinates of the meteorological station locations are the following:

Table 1. Coordinates of 6 ground weather stations in Uzbekistan, established with the assistance of ADB

\begin{tabular}{|c|c|c|c|c|}
\hline $\mathrm{N}^{\mathrm{o}}$ & Province & Name & Coordinates $\mathrm{N}$ & Coordinates $\mathrm{E}$ \\
\hline 6 & Tashkent & Parkent District, 'Solar' Village & 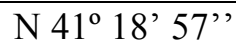 & E $69^{\circ} 44^{\prime} 28^{\prime}$ \\
\hline 8 & Navoi & KarmanaVillagemeteostation & $\mathrm{N} 40^{\circ} 08^{\prime} 43^{\prime \prime}$ & E $65^{\circ} 18^{\prime} 32^{\prime \prime}$ \\
\hline 14 & Samarkand & Samarkandcitymeteostation & 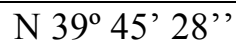 & E $66^{\circ} 54^{\prime} 54^{\prime \prime}$ \\
\hline 22 & Namangan & Pap city meteostation & $\mathrm{N} 40^{\circ} 52^{\prime} 41^{\prime \prime}$ & E $71^{\circ} 06^{\prime} 43^{\prime \prime}$ \\
\hline 30 & Surkhandarya & Sherabadcitymeteostation & 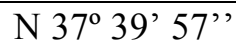 & $\mathrm{E} 67^{\circ} 00^{\prime} 31^{\prime \prime}$ \\
\hline 31 & Kashkadarya & Guzarcitymeteostation & N $38^{\circ} 37^{\prime} 05^{\prime \prime}$ & E $66^{\circ} 15^{\prime} 17^{\prime \prime}$ \\
\hline
\end{tabular}

All 6 stations are identical in design and have the same quantity and model of apparatus. Every station is equipped with a date logger and a standard set of instruments which include ventilated pyranometers, pyrheliometers (solar radiation meters); air temperature, barometric pressure, atmospheric visibility sensors, anemometers, wind vane and rain gauges (meteorological parameter meters). It should be noted here that only first class pyrheliometers and secondary standard pyranometers as classified by ISO 9060 [8] are used in this network.

\section{Data analysis}

The analysis uses 4-year (January 2013-December 2016) data from 6 stations located in the south-eastern part of the republic based on ten-minute measurements of Global Horizontal Irradiance (GHI), Diffuse Horizontal Irradiance (DHI), Direct Normal Irradiance (DNI), and related meteorological parameters. The data measured by the stations is received and stored in a Central Receiving Station located at Physical-Technical institute under the Academy of Science in Tashkent.

It should be considered that since values presented here are based on only four year groundmeasurements, they should not be mistaken to represent "long-term average", although these values can be used as a rough estimate of the values that can be expected in regions that have similar climatic conditions.

Fig. 2 summarizes the average solar radiation level by characteristic regions of the Republic. 


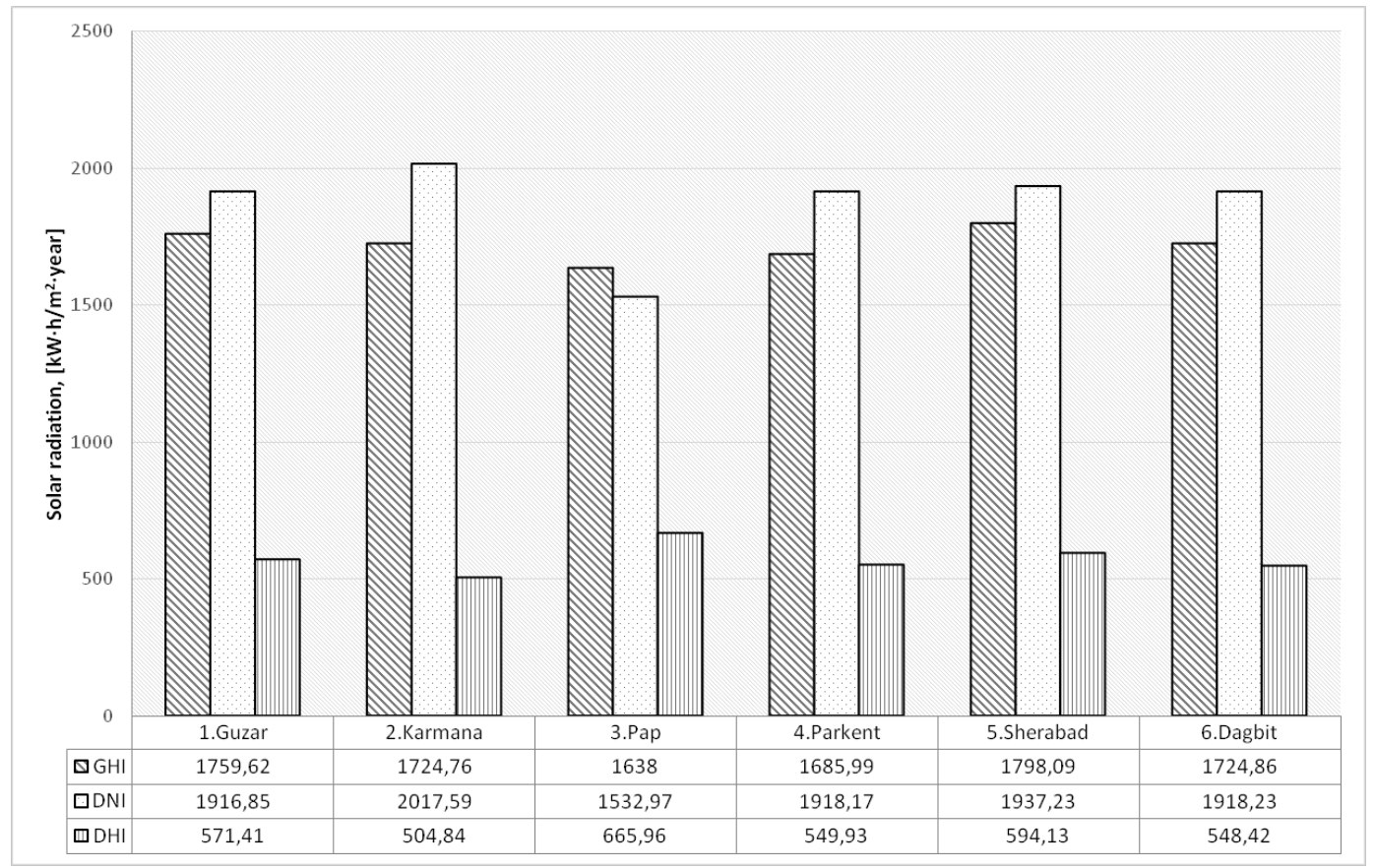

Fig.2.Total solar radiation in the specific regions of the republic of Uzbekistan

The monthly values of direct normal irradiance for selected sites have also been obtained. To demonstrate the pattern of DNI change throughout the year the Tashkent city is given as an example (Fig.3)

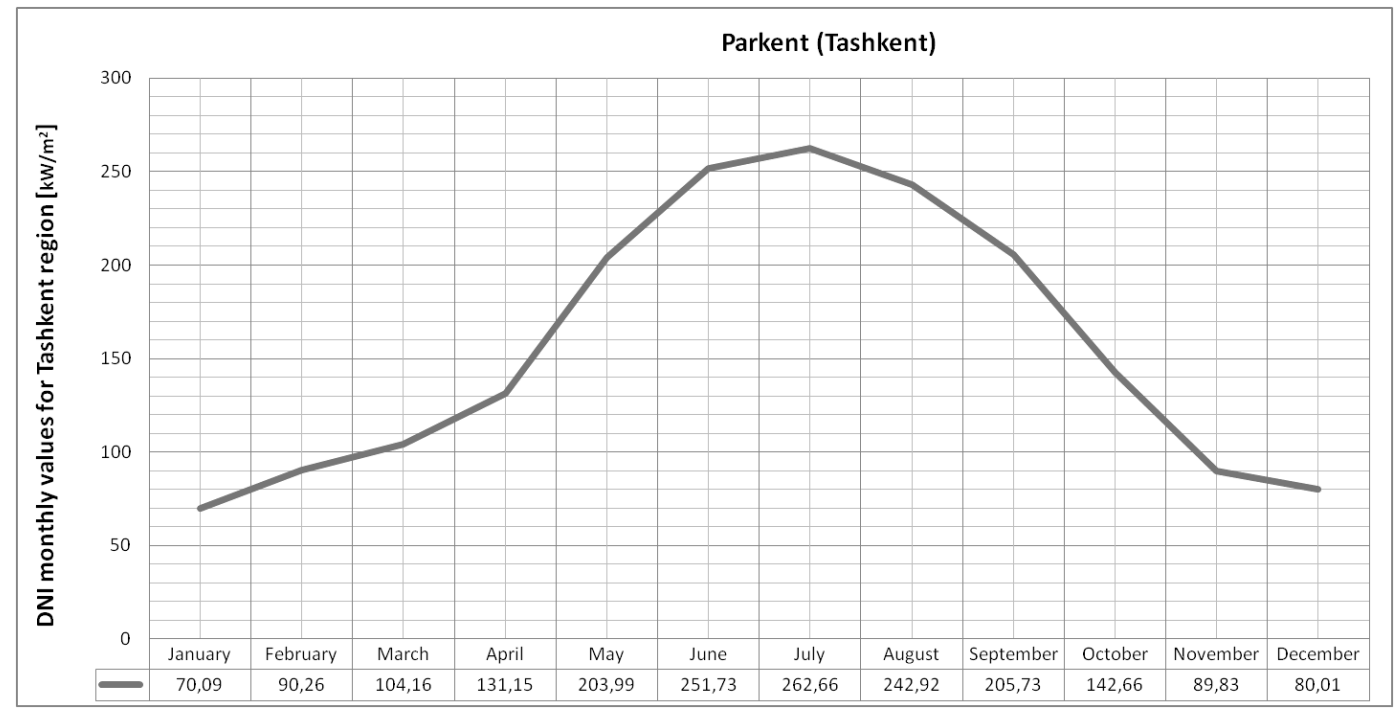

Fig.3.Monthly values of direct normal irradiance for Tashkent region

The data gathered during four years in ground meteorological stations has been correlated with 13 year satellite data to estimate the long term solar resource in the selected sites (Fig.4). 


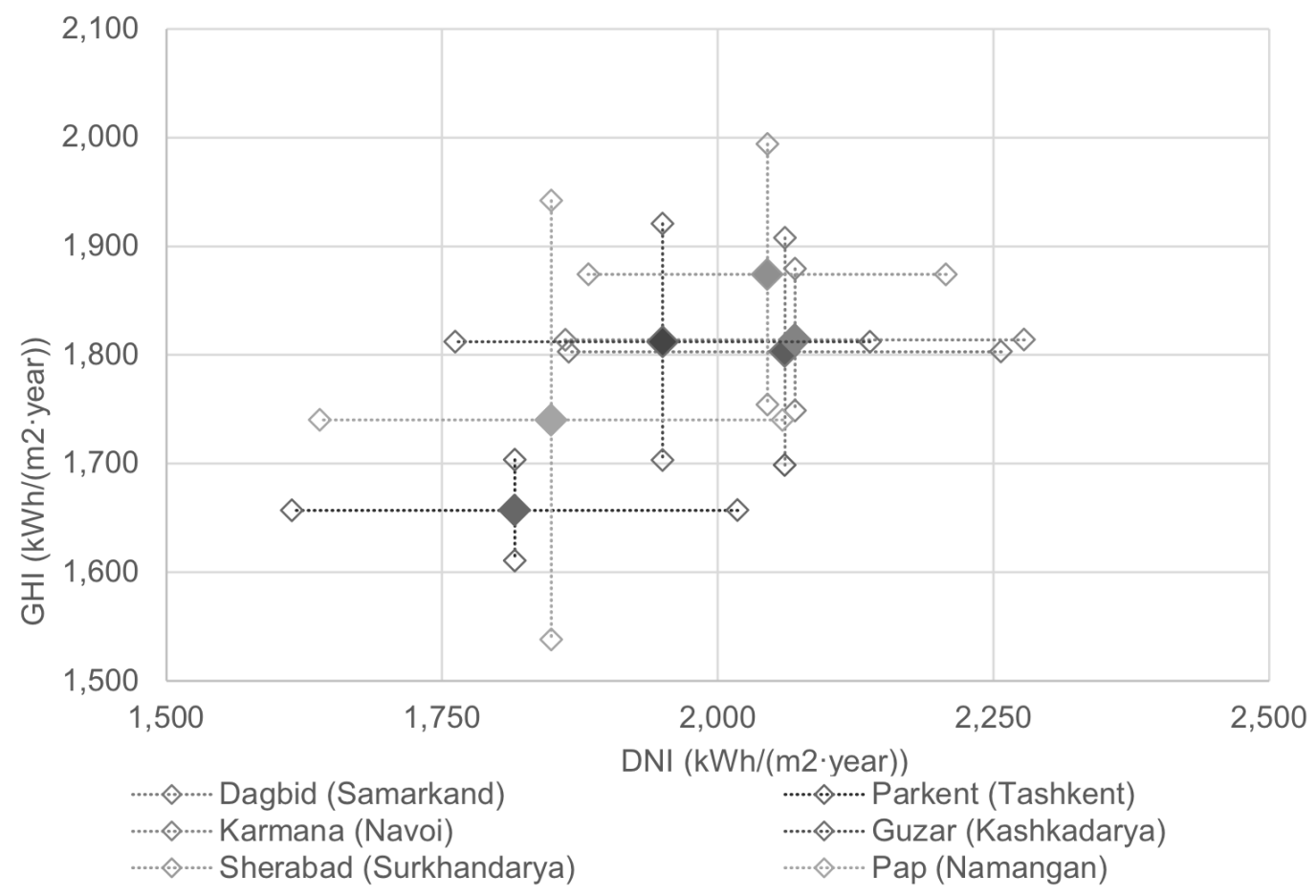

Fig.4. Long term yearly irradiation and error on the six meteorological stations site (15 years satellite data calibrated with 4 years on-site measurement)

Thus, there are locations with GHI higher than $1.700 \mathrm{kWh} / \mathrm{m}^{2}$ year and DNI higher than 2.000 $\mathrm{kWh} / \mathrm{m}^{2}$ year which are suitable to set up solar energy power plants, both CSP and PV. Considering only the criteria of higher resource available to prioritize, and based on the values shown in Fig. 2, the potential suitable locations to develop CSP and PV are shown in Tab.2:

Table2.The most optimal places for the deployment of CSP and PV in the republic of Uzbekistan according to preliminary assessment (the levels of GHI and DNI are considered as criteria for assessing)

\begin{tabular}{|c|c|c|c|c|c|c|}
\hline & $\begin{array}{l}\text { Best } \\
(+)\end{array}$ & & & & & $\begin{array}{l}\text { Worst } \\
(-)\end{array}$ \\
\hline $\begin{array}{l}\text { CSP } \\
\text { (Solar } \\
\text { res: } \\
D N I \text { ) }\end{array}$ & Navoi & Surkhandarya & Tashkent & Kashkadarya & Samarkand & Namangan \\
\hline $\begin{array}{l}P V \\
\text { (Solar } \\
\text { res: } \\
G H I)\end{array}$ & Surkhandarya & Kashkadarya & Samarkand & Navoi & Tashkent & Namangan \\
\hline
\end{tabular}




\section{Conclusions}

Thereby, the intensity of solar radiation on the territory of the republic varies from $1500 \mathrm{kWh} /$ $\mathrm{m}^{2}$ per year for the Fergana Valley to $2100 \mathrm{kWh} / \mathrm{m}^{2}$ per year for the North of the Republic. The minimum and maximum values of the monthly DNI for the city of Tashkent are observed in January (70.09 kWh / $\mathrm{m}^{2}$ per month) and July (262 kWh / $\mathrm{m}^{2}$ per month), respectively.

In accordance with the national concept for the development and implementation of renewable energy in Uzbekistan, it is planned to build stand-alone and grid interactive solar power plants with a capacity of 10 to $25 \mathrm{MW}$ in each region throughout the republic.

The 6 meteorological stations are distributed mainly in the Southeast and South parts of Uzbekistan where government is expecting the highest numbers of solar energy projects to be launched by 2030. Although, the number of installed meteorological stations are need to be increased and the measurement process should be combined with satellite-derived solar data, it is evident that developing solar plants in Uzbekistan is an option which would assure sustainability, liberate national natural gas for export purposes and contribute to future country energy security.

\section{References}

[1] IEA, World Energy Outlook 2016, www.worldenergyoutlook.org

[2] Daus J.V., Kharchenko V.V., Assessment of the Applicability of Data on the Intensity of Total Solar Radiation from Various Sources of Actinometric Information (in russian language),Geliotekhnika, 2, (2017), pp. 48-54

[3] StackhouseP. W., Whitlock C. H. et al, Meeting Energy-Sector Needs with NASA Climate Datasets,Earth Observation Magazine, 11, (2002), pp.6-10

[4] Meteotest, Meteonorm, 2008.

[5] Michalsky J., Berndt J. L., A Microprocessor Based Rotating Shadowband Radiometer. Solar Energy,3,(1986), pp.381-479.

[6] Avezov R.R., Lutpullaev S. L.,The state, prospects and problems of using renewable energy in Uzbekistan. Physics in Uzbekistan,2, (2005), pp.119-123

[7] UZBTA 8008 ADB Roadmapto solar energy development in Uzbekistan, 2013.

[8] ]ISO 9060 1990, Solar energy - Specification and classification of instruments for measuring hemispherical solar and direct solar radiation, International Organization for Standardization, 2008. 